\title{
EMOTIONAL FACTORS PRIOR TO CATARACT SURGERY
}

\author{
Roberta Marback, Edméa Temporini, Newton Kara Júnior
}

Marback R, Temporini E, Kara Júnior N. Emotional factors prior to cataract surgery. CLINICS. 2007;62(4):433-8.

PURPOSE: Identification of emotional factors related to daily difficulties and surgical treatment among patients with cataract at a university hospital.

METHODS: A cross-sectional study was carried out by means of a questionnaire, elaborated based on a previous study. The sample consisted of patients seen at the cataract unit of the ophthalmology clinic of a university hospital.

RESULTS: The sample consisted of 110 individuals of both sexes (34.5\% men; $65.5 \%$ women) between the ages of 43 and 89 (average $69.0 \pm 10.3$ years); $26.4 \%$ had never attended school, $59.1 \%$ had primary education, and $87.3 \%$ had no payed occupation. Most of the patients reported daily difficulties due to their ocular condition (82.7\%), and 54.0\% reported fear of visual loss. Doubt as to the outcome $(32.7 \%)$, distress $(26.4 \%)$, and sadness $(25.5 \%)$ were reported.

CONCLUSIONS: Most of the patients reported difficulties in daily activities as a consequence of cataract. Fear was the predominant feeling related to undergoing surgery. The findings suggest the need for implementing intervention courses for emotional preparation for facing daily activities and cataract surgery.

KEY WORDS: Psychology. Cataract. Visual loss. Surgery. Public Health

\section{INTRODUCTION}

Senile cataract is one of the leading causes of blindness in the world, responsible for $50 \%$ of the cases. Despite being considered an inevitable ocular condition, it is liable to recovery through a specific surgical procedure. ${ }^{1}$

Studies have shown that even though visual function may be recovered and specialized treatment services are available, there are still barriers to overcome. These range from access and economical difficulties to psychological and socio-cultural influencing factors, such as beliefs, values, and the individual's attitudes and perceptions, as well as fear, lack of confidence, and insecurity. ${ }^{2,3}$

Patients with cataracts tend to show high levels of anxiety during the pre and postoperative periods as well as during surgery. Lack of information about the surgical procedure and also expectations regarding results may be the rea-

Department of Ophthalmology, São Paulo University Medical College E-mail: robertamarback@uol.com.br

Received for publication on March 01, 2007

Accepted for publication on April 23, 2007 son for this anxiety and fear. ${ }^{4,5}$

Any health education intervention must be preceded by the understanding of the meaning and dimensions attributed by the subjects to the illness process, enabling understanding of the underlying significance of behaviors concerning disease prevention, control, and treatment. ${ }^{6}$

One of the most important factors regarding patient satisfaction is information on medical procedures. Preoperative orientation is associated with lower levels of anxiety, lower complication rates, and length of stay in hospital, as well as with less pain and better patient satisfaction. ${ }^{7}$

Health care professionals other than the doctors can contribute to improved communication, through joint efforts of ophthalmologists, health care educators, teachers, psychologists, social workers, occupational therapists, and ophthalmology nurses. ${ }^{8}$ A study of the understanding of ocular health among professionals of a university hospital showed that although most of the staff declared knowing what cataract is, incorrect definitions of this condition were presented, even by ophthalmology personnel. ${ }^{9}$ Therefore, train- 
ing in specialized centers is recommended to guide the target population about eye disorders.

Among the multiple aspects of scientific knowledge on cataracts, identification of emotional factors related to daily difficulties and surgical treatment among patients with cataracts was the focus of this study. We believe that more subsidies in support of educational intervention planning are necessary in order to prepare patients for cataract surgery.

\section{MATERIALS AND METHODS}

A cross-sectional study was carried out by means of a closed questionnaire built upon data previously collected from an exploratory study, taking into consideration the terms used by the responders and their experiences (see Appendix). Negative feelings regarding cataract surgery were assessed in the questionnaire through reported fear and emotional meaning attributed to the fact (distress, anger, sadness, and rejection). The questionnaire had been previously submitted to a test of clarity, accuracy, and validity.

The sample comprised patients seen during the first semester of 2005 at the ophthalmology clinic of a university hospital. The following inclusion criteria were established: individuals of both sexes, aged 40 or older, diagnosed with cataracts, with surgical indication, and willing to be interviewed.

The variables included socio-demographic factors-gender, age, and educational level. The assessment of the subject's perception of cataract was based on the meaning attributed to the ocular condition resulting from experiences known through or lived in their social groups. The patients expressed an "opinion," i.e., a measurable verbal manifestation, reflecting perceptions about specific situations proposed by the assessment tool. Data were collected through individual interviews, and no patient refused to cooperate. The interviews were conducted by one of the authors and took place in the waiting room of the ambulatorial surgical center for cataracts. The previous test had been performed with 30 persons, and only after the analysis of the answers, modifications, and re-tests, was it considered in condition to be applied to this study. The study was previously approved by the Institution's Ethics Committee.

\section{RESULTS}

The sample consisted of 110 individuals of both sexes (34.5\% men; $65.5 \%$ women) between the ages of 43 and 89 (average 69.0 years, \pm 10.3 years). Concerning educational level, $26.4 \%$ had never attended school, 59.1\% had attended primary school, $10.9 \%$ had attended secondary school, and $3.6 \%$ had reached undergraduate education;
$87.3 \%$ held no paid occupation. Of these, $5.2 \%$ were reportedly retired; $17.7 \%$ received a stipend; $17.7 \%$ had no possibility of working; $7.3 \%$ performed housework, and $2.1 \%$ had not been able to get a job.

Daily difficulties due to the ocular condition were reported by $82.7 \%$. Doing housework $(64.8 \%)$, walking $(72.5 \%)$, and watching TV $(64.8 \%)$ were the most frequently reported difficulties (Table 1).

Table 1 - Daily difficulties as a result of cataracts $(\mathrm{N}=110)$

\begin{tabular}{lcc}
\hline Difficulties & $\mathrm{n}$ & $\%$ \\
\hline None reported & 19 & 17.3 \\
Reported & 91 & 82.7 \\
Difficulty in: & $\mathrm{n}=91^{*}$ & \\
· housework activities & 59 & 64.8 \\
· walking & 66 & 72.5 \\
· watching TV & 59 & 64.8 \\
- others & 27 & 29.7 \\
\hline
\end{tabular}

*Multiple answers

As for fear, $33.3 \%$ of the patients reported fearing the surgical procedure, $54.0 \%$ feared visual loss, and $12.7 \%$ feared death during surgery. Regarding the level of fear and acceptance, $12.7 \%$ reported being very much afraid, while $29.1 \%$ reported being somewhat afraid, and $58.2 \%$ felt no fear at all (Table 2).

Table 2 - Fear and acceptance of cataract surgery $(\mathrm{N}=110)$

\begin{tabular}{lll}
\hline Fear/Acceptance of the surgery & $\mathrm{n}$ & $\%$ \\
\hline Of the surgical procedure $\quad \mathrm{n}=102^{*}$ & 34 & 33.3 \\
Of losing eyesight & 55 & 54.0 \\
Of dying during surgery & 13 & 12.7 \\
Declared being: & & \\
• very much afraid, but accepted the fact & 14 & 12.7 \\
· somewhat afraid, but accepted the fact & 32 & 29.1 \\
· not afraid and accepted the fact & 64 & 58.2 \\
\hline
\end{tabular}

*Affirmative answers

With respect to the surgical procedure, doubt as to the outcome $(32.7 \%)$, distress/anxiety $(26.4 \%)$, sadness $(25.5 \%)$, happiness $(10.9 \%)$, and anger $(4.5 \%)$ were mentioned (Table 3).

Table 3- Importance/feelings towards undergoing cataract surgery $(\mathrm{N}=110)$

\begin{tabular}{lcc}
\hline Importance/feeling & $\mathrm{n}$ & $\%$ \\
\hline Distress & 29 & 26.4 \\
Doubt as to the outcome of the surgery & 36 & 32.7 \\
Anger for needing to undergo surgery & 5 & 4.5 \\
Sadness & 28 & 25.5 \\
Happiness & 12 & 10.9 \\
\hline
\end{tabular}


When comparing cataract surgery to other kinds of surgery, $47.3 \%$ thought it was better to undergo eye surgery, $5.5 \%$ said both situations were the same, $4.5 \%$ thought that cataract surgery was worse, and $42.7 \%$ had no opinion on the matter (Table 4).

Table 4 - Importance attributed to cataract surgery $(\mathrm{N}=110)$

\begin{tabular}{lcc}
\hline When compared to other types of surgery & $\mathrm{n}$ & $\%$ \\
\hline Operating cataract is: & & \\
- worse & 5 & 4.5 \\
the same & 6 & 5.5 \\
- better & 52 & 47.3 \\
- no opinion & 47 & 42.7 \\
\hline
\end{tabular}

\section{DISCUSSION}

It is an established fact that in Brazil, public health care settings such as a university hospital largely serve patients at the margin of any medical assistance, i.e., individuals who cannot contribute monetarily towards social services, a fact which was confirmed in the study sample. ${ }^{10}$ The search for free health care services is usually the consequence of being part of lower income populations.

Visual limitations imposed by the cataract when performing daily activities, as observed in this study, suggest quality of life impairment from personal limitations. ${ }^{11}$ At the time of writing, surgical interventions are usually performed earlier, and both recovery and results have been very satisfactory due to advances in surgical techniques. Furthermore, it has been observed that the patient's improvement is inversely proportional to the severity of his/her visual damage in the preoperative period. ${ }^{12}$ Thus, other important barriers to visual recovery include possible reluctance to seek treatment and/or lack of opportunity to undergo surgery. The perceptions about the disease depend on sociocultural influences and the degree of impossibility of performing daily activities. ${ }^{6}$

The common misconception that cataract is the inevitable result of the aging process and that "there is nothing we can do about it," leads to a fatalistic attitude and to a consequent acceptance of blindness as the ultimate result. This erroneous way of thinking influences the individual's behavior and hinders access to surgery. ${ }^{13}$

Even if these barriers are overcome, there are still other emotional and mental limitations that create apprehension and insecurity about the surgical procedure. Considering these aspects, it is appropriate to investigate the reasons for the fear of cataract surgery.

A study carried out with patients assisted by Projeto Catarata [Cataract Project], developed in a university hos- pital, also assessed fears, identifying the presence of fear of surgery (28.8\%), fear of going blind $(55.1 \%)$, and fear of feeling pain $(40.8 \% \text {. })^{14}$

A study with patients in the preoperative period, carried out in 2 different hospitals with different anesthesia procedures (one used sedatives before anesthesia), highlighted the fact that anesthesia-related fear was less in patients who received pre-anesthetic sedatives, as compared to the other group receiving none. Patients reported being afraid of the surgical procedure due to fear of pain during the procedure, lack of orientation in the preoperative period, and as part of each person's strategy to cope. ${ }^{4}$

Anesthesia usually produces more fear than the surgery itself. This feeling can be linked to the idea of losing control, absence, disconnection, separation, and death. The participation of the doctor and other professionals in explaining, understanding, and calming down the patient is extremely important for reducing anxiety and its consequences. ${ }^{4}$

A significant proportion of the patients declared having doubts as to the outcome of the surgical procedure (Table 3). This fact may also be related to poor communication between doctor and patient, which highlights the importance of the doctor showing willingness to offer explanations that are adapted to the patient's ability to understand.

Medical orientation tends to reduce anxiety and reinforce proper defense strategies. It is expected that the patient should be prepared for the procedure, feeling capable of working with the team for a good outcome. More information reduces surgery cancellations. Lack of, or inadequate information may contribute to anxiety and lead to surgical complications as pointed out by Morrell, ${ }^{15}$ who showed that $67 \%$ of the patients who received information had a more positive outcome, but favorable outcomes were $20 \%$ higher than in those who received no information whatsoever.

Another study showed that an intervention such as a preoperative videotape explaining to patients the sensations they are likely to experience during surgery, along with common outcomes and risks, reduces anxiety and improves patient satisfaction following cataract surgery. These explanations constitute a simple intervention with benefits for the patient, surgeon, and the community. ${ }^{16}$

This reinforces the relevance of preoperative orientation and its influence on the outcome of the surgery. Likewise, the diagnosis and treatment provided by the doctor must make sense to the patient, considering the patient's lay perception of the health problem as well as acknowledging and respecting the patient's personal experience and opinions on his or her own condition. ${ }^{17}$

Properly elaborated instructions transmitted to patients were found to significantly reduce the level of anxiety, based on an anxiety scale (Spielberger State-Trait Anxiety Inven- 
tory - STAI). ${ }^{15}$ This, in turn, contributed to treatment effectiveness and patient cooperation at the time of surgery.

It is worth mentioning that for better acceptance of a medical treatment by patients, it must make sense to them. The patient's comprehension of the disease process and its treatment is of key importance.

Nevertheless, the amount of information wanted seems to vary from patient to patient. It is worth considering that, despite the benefits, many patients tend to not request or even tend to avoid information, arguing that more information produces more anxiety. ${ }^{7}$

In general, patients prefer oral to written or interactive information. Oral information seems to be more effective due to the interpersonal contact. ${ }^{4}$

A study in which the authors applied a similar questionnaire to patients from private and public clinics requiring cataract surgery, as well as to surgeons, showed discrepancies between what doctors consider to be priorities for patients and what the patients themselves actually consider as priorities. The most striking disparities were seen in the priorities set by public service patients. This may be due to the fact that these patients did not feel comfortable in clearly expressing their priorities to the doctors. Or, on the other hand, due to the demand, the doctors did not have enough time to discover the patients' priorities, anxiety levels, and personal standpoints. ${ }^{7}$

However, the need to re-evaluate the health care system is evident in a scenario where an excess demand for health care services contrasts with an insufficient number of professionals, whose time is already scarce for their regular activities. Consequently, tiredness, frequently observed in these professionals, leads to inadequate communication between the health care professional and the patient. This faulty communication interferes directly with the patient's treatment. In this situation, the interdisciplinary work of the health care team focusing on the patients' reactions towards treatment is extremely important. Preoperative orientation is necessary in order to ease the suffering caused by surgery and render satisfaction with the treatment. This educational approach also brings benefits to the team, since by paying attention to the patients' subjective feelings, one might expect a drop in cancellations of surgical procedures and appointments as well as a decrease in surgical complications.

\section{ACKNOWLEDGEMENT}

This research was supported by a grant from "Coordenação de Aperfeiçoamento de Pessoal de Nível Superior (CAPES - MEC)", Brasília, Brazil.

\section{RESUMO}

Marback R, Temporini E, Kara Júnior N. Fatores emocionais antecedentes à cirurgia de catarata. CLINICS. 2007;62(4):433-8.

OBJETIVO: Identificar fatores emocionais relacionados às dificuldades cotidianas e ao tratamento cirúrgico entre portadores de catarata de hospital universitário.

MÉTODOS: Realizou-se estudo observacional transversal descritivo, por meio de questionário estruturado, aplicado por entrevista, elaborado a partir de estudo exploratório. A amostra foi formada por pacientes atendidos pelo setor de catarata da clínica oftalmológica de um hospital universitário. RESULTADOS: A amostra foi constituída por 110 sujeitos de ambos os sexos (34,5\% homens; 65,5\% mulheres), com idade entre 43 e 89 anos, $\pm 10,3$ anos. Quanto à escolaridade, $26,4 \%$ nunca freqüentaram escola, $59,1 \%$ se distribuíram entre $1^{\mathrm{a}}$ e $8^{\mathrm{a}}$ série $\left(1^{\mathrm{o}}\right.$ grau); $87,3 \%$ não exerciam atividade remunerada. A maior proporção dos entrevistados referiu dificuldades cotidianas devido à afecção ocular $(82,7 \%)$. Quanto ao medo em relação à cirurgia de catarata, 54,0\% mencionaram medo de perder a visão. Foram registrados sentimentos/significações em relação ao procedimento cirúrgico: dúvida quanto ao resultado $(32,7 \%)$, angústia $(26,4 \%)$, tristeza $(25,5 \%)$.

CONCLUSÕES: A maioria dos entrevistados referiu dificuldades nas atividades cotidianas como consequiência da catarata. Medo foi sentimento predominante entre os respondentes. Esses fatos sugerem necessidade de implementação de ações junto a pacientes, visando preparo emocional para enfrentamento das atividades cotidianas e da cirurgia de catarata.

UNITERMOS: Psicologia. Catarata. Perda Visual. Cirurgia. Saúde Pública. 


\section{REFERENCES}

1. Resnikoff S, Pascolini D, Etya'ale D, Kocur I, Pararajasegaram R, Pokharel GP, et al. Global data on visual impairment in the year 2002. Bull World Health Organ. 2004;82:844-51.

2. Kara-José Jr N, Schellini AS, Silva MRBM, Bruni LF, Almeida AGC. Projeto catarata—qual a sua importância para a comunidade? Arq Bras Oftalmol. 1996;59:490-6.

3. Temporini ER, Kara-José N, Kara-José Jr N. Catarata senil: características e percepções de pacientes atendidos em projeto comunitário de reabilitação visual. Arq Bras Oftalmol. 1997;60:79-83.

4. Nijkamp MD, Ruiter RAC, Roeling M, Van Der Borne B, Hiddema F, Hendrikse F, et al. Factors related to fear in patients undergoing cataract surgery: a qualitative study focusing on factors associated with fear and reassurance among patients who need to undergo cataract surgery. Patient Educ and Couns. 2002;47:265-72.

5. Nijkamp MD, Kenens AJ, Dijker AJM, Ruiter RAC, Hiddema F, Nuijts RMMA. Determinants of surgery related anxiety in cataract patients. Br J Ophthalmol. 2004;88:1310-4

6. Briceño-León R. Siete tesis sobre la educación sanitaria para la participación comunitaria. Cad. Saúde Públ. 1996;12:7-30.

7. Pager CK, Med B, Dip E, McCluskey PJ. Surgeons' perceptions of their patients' priorities. J Cataract Refract Surg. 2004;30:591-7.

8. Temporini ER, Kara-José N, Rigolizzo HB. Envolvimento de pessoal da comunidade em projeto de detecção de ambliopia em pré-escolares. Arq Bras Oftalmol. 1983;46(3):85-9.
9. Temporini ER, Kara-José N, Gondim ÉL, Dantas FJ. Conhecimentos sobre saúde ocular entre profissionais de um hospital universitário. Medicina, Ribeirão Preto. 2002;35:53-61.

10. Marback RF, Temporini ER, Maia Jr OO, Schaefer T, Kara José Jr N, Kara José N. Atividade ocupacional e catarata senil - opinião de pacientes de hospital universitário. Medicina, Ribeirão Preto. 2005;38:301-9.

11. Kara Jr N, Temporini ER, Kara José N. Cataract surgery: expectations of patients assisted during a community project in São Paulo, state of São Paulo, Brazil. Clinics. 2001;56:163-68.

12. Wormald R. Cataract surgery - quantity and quality. Br J Ophthalmol. 1999;83:889-90.

13. Temporini ER, Kara-José N, Kara-José Jr N. Catarata senil: características e percepções de pacientes atendidos em projeto comunitário de reabilitação visual. Arq Bras Oftalmol. 1997;60:79-83.

14. Oliveira RSCS, Temporini ER, Kara José N, Carricondo PC, Kara José AC. Perceptions of patients about cataract. Clinics. 2005;60:455-60

15. Morrell, G. Effect of structured preoperative teaching on anxiety levels of patients scheduled for cataract surgery. Insight. 2001;26:4-9.

16. Pager CK. Randomised controlled trial of preoperative information to improve satisfaction with cataract surgery. Br J Ophthalmol. 2005;89:103.

17. Helman CG. Interações médico-paciente. In: Helman CG. Cultura, saúde $\&$ doença (Culture, health and illness). $4^{\mathrm{a}}$ ed. Porto Alegre: Artmed; 2003. p.109-45. 
APPENDIX

SURVEY QUESTIONNAIRE

CATARACT SURGERY: MEANING FOR PATIENTS, 2005

QUESTIONNAIRE $\mathrm{N}^{\circ}-\frac{-1}{2}-$

\begin{tabular}{|l|}
\hline $\begin{array}{l}\text { M Gender: } \\
\text { Male } \\
\text { Female }\end{array}$ \\
\hline $\mathbf{2}$ How old are you? \\
\hline 3 Did you go to school? If yes: \\
Up to which grade? \\
Primary school (or equivalent): Up to \\
Secondary school (or equivalent) : Up to \\
Undergraduate education: \\
$\quad$ - incomplete \\
$\quad$ - complete \\
Did not study
\end{tabular}

4 Do you currently have a remunerated occupation, yes or no?

If yes: What is your occupation?

Does not work

Remunerated occupation (skip to question 6) _ _ (2)

\begin{tabular}{ll}
\hline \multicolumn{1}{c}{ (Occupation) } \\
$\mathbf{5}$ You do not work because you: \\
- are retired? \\
- cannot get a job? \\
- cannot work? \\
- Other? \\
Explain:
\end{tabular}

6 Do you have difficulties in performing daily activities due to poor eyesight?

No difficulties (skip to question 8) _ (1)

Difficulties $\quad$ - (2)

7 Do you experience difficulties in doing housework, walking on the street, watching TV, reading the newspaper, a magazine or book, sewing, driving, or doing minor home repairs? (ONE OR MORE ANSWERS)

Difficulty in:

- doing housework

- walking

- watching TV

- reading a newspaper, magazine or book

- other

Yes (1) No (2)

Yes (1) No

-- -

8 How did you feel when you were informed you had to undergo surgery?

- Afraid of the operation?

- Afraid of losing your eyesight?

- Afraid of dying during the operation?

Yes (1) No (2)

9 When you were informed you needed eye surgery, were you very much afraid, somewhat afraid but accepted the fact, so afraid you did not want to undergo surgery, or not afraid at all?

- very much afraid but accepted the fact

- somewhat afraid but accepted the fact

- not afraid at all

- (2)

10 What else did you feel?:

- Distress?

- Doubt as to a positive result?

- Anger for needing to undergo surgery

- Sadness for needing to undergo surgery?

- Other?

- Explain:

11 In your opinion, is eye surgery worse, the same or better than other types of surgery? Or do you not know?

Worse

$\begin{array}{ll}\text { Yes (1) } & \text { No (2) } \\ -- & -- \\ -- & -- \\ -- & -- \\ -- & -- \\ - & --\end{array}$

The same candy

Better

No opinion 